VAK 342

ББК 67.400

DOI 10.22394/1682-2358-2018-5-23-28

D.S. Velieva, Doctor of Sciences (Law), Professor, Head of the Constitutional and International Law Department, Povolzbsky Institute of Manasement named after P.A. Stolypin, Branch of the Russian Presidential Academy of National Economy and Public Administration

\section{CONSTITUTIONAL CONCEPTUALIZATION OF NATIONAL INTERESTS IN MODERN RUSSIA}

The essence and purpose of the Constitution of the Russian Federation, its importance for the development of the Russian state and society are investigated. The significance of the Constitution as a legal basis for ensuring constitutional values and national interests, the stability of the constitutional and legal development of the Russian state is analyzed. The comprehensive nature of national interests and the need to harmonize the interests of the individual, society and the state in solving political, economic, social and other problems are noted.

Key words and word-combinations: national interests, public and private interests, the constitution of Russia.
А.С. Велиеба, доктор торидиеских наук, профессор, заведующий кафедрой конституционного и межжуннародного права Поволжского института управления имени П.А. Стольгпина - филиала Российской академии народного хозяйства и государственной службь при Президенте РФ (email: jamiliavelieva@yandex.ru)

\section{КОНСТИТУЩИОННАЯ КОНЦЕПТУААИЗАЦИЯ НАЦИОНААЬНЬХ ИНТЕРЕСОВ В СОВРЕМЕННОЙ РОССИИ}

Аннотация. Исследуются сущность и предназначение Конституции РФ, ее значение для развития Российского государства и общества. Анализируется значимость Конституции как правового фундамента обеспечения конституционных ценностей и национальных интересов, стабильности конституционно-правового развития Российского государства. Отмечается комплексный характер национальных интересов и необходимость согласования интересов личности, общества и государства при решении политических, экономических, социальных и иных проблем.

Ключевые слова и словосочетания: национальные интересы, публичные и частные интересы, Конституция России.

B преалверии 25-летнего юбилея Конституции РФ на страницах юридической митературы широко обсужАались проблемы становления правового, демократического, соџиального государства в России, обеспечения верховенства права, конституционного правопорядка, гарантированности прав человека, соотношения норм национаць- 
ного законодательства и международного права, эффективности публичной власти. Объектом пристального явицись вопросы соотношения фактической и юридической конституции, модернизации федеративных отношений, развития парламентаризма, реформирования избирательной и судебной системы. Предметом научной дискуссии в современной Аоктрине конституџионного права выступает и предназначение самой конституции, проблемы ее прямого Аействия, стабильности и ценностное значение.

Аействующая Конституция РФ 1993 г. определика конституционные параметры развития Российского государства, закрепила новую конџепџию прав человека, установияа совершенно новые принципы взаимодействия государства, общества и личности. Основное ее достижение заключается в том, что она содержит базовые ценности, способствующие установлению правопорядка в обществе и уравновешиванию социальных противоречий. Как справедииво отмечает Н.С. Бондарь, «Конституџия в этом пмане предстает как отражение и нормативная правовая форма обеспечения сбалансированной реализаџии высших социальных ценностей, нравственно-юридических установок многонационацьного народа России» [1, с. 13].

Современные авторы видят социально-юридическую сущность Конституции в закреплении Основным Законом совпадающих жизненных интересов народа, признании общечеловеческих ценностей. Как акт высшей юридической силы Конституция РФ отражает потребности государства и общества в политической, экономической, соџиальной, Ауховной сферах, выступает юридическим выражением, квинтэссенцией жкизненно важных интересов народа.

Современный этап развития государства, характеризующийся политическими, соџиально-экономическими сложностями, требует «закрепления юридических механизмов преодоления соответствующих противоречий, конфииктов и комлизий, нормативного моделирования развития общества и государства в соответствии с провозглашенными конституџионными цемями, признаваемыми ценностями и идеалами» [2, с. 7]. Такой подход к сущности Конституции РФ представляется верным, поскольку «глобальная конкуренция, присущая постиндустриальному развитию человечества, остро ставит и вопрос о способности Российского государства гарантировать национацьные интересы страны, сохраняя при этом ее цивицизационную и государственную идентичность [3, с. 14]. Отсюда следует задача современной Конституџии страны, которая заключается в обеспечении конституционных принципов, ценностей и национальных интересов.

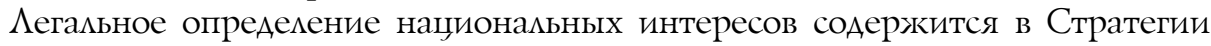
национальной безопасности Российской Федерации - это объективно значимые потребности мичности, общества и государства в обеспечении их защищенности и устойчивого развития [4]. Обеспечение защиты национацьных интересов как высшей социальной ценности составляет фундаментальную функцию Российского государства. Его следует рассматривать как непременное условие и гарантию совершенствования обшественных отношений, успешной жизнедеятельности государства, незыблемости конституџионных прав и свобод гражАан. 
Определяющую роль в обеспечении государственных интересов, интересов цичности и общества играет законодательное регулирование, при этом национальные интересы выполняют роль реального базиса правовой политики государства. Они выступают тем ориентиром, который способен придать ей высший ценностный смысл и «выстроиты» осязаемые, фактически Аостижимые текущие и перспективные цеми. Право на этом пути - один из главных инструментов, который призван оберегать национамьные интересы, но не препятствовать их реализаџии, не осложнять функционирование $[5$, с. 87].

В системе приоритетных целей развития государства обеспечение наџиональных интересов занимает особое место. Этим объясняется широкое использование представителями размичных научных направлений в своих трудах понятия «национальный интерес». Комплексный характер вопросов, связанных с обеспечением национальных интересов, обусловливает необходимость осуществления системы мер - политических, правовых, организационных, экономических, идеологических. Их реализация, в свою очередь, преАполагает законодательную регламентацию содержания и объема полномочий органов государственной власти и органов местного самоуправления в конкретной сфере.

Термин «национальный интерес» вошел в научный оборот сравнительно недавно. Этимологическое и политико-правовое значение данного термина и его связь с понятием национальной безопасности требует современной интерпретации содержания в условиях глобализаџии. Наџиональный интерес не совпадает с общественным интересом. В отличие от общественного интереса, который регулируется и связан с системой законов, определяющих внутригосударственную политику, наџиональный интерес относится к сфере внешней политики государства. Примечательно, что сторонники строгого понимания категории «наџиональный интерес» как в теории, так и в политической практике придерживаются этого разделения: «Так же как понятие «общественный интерес» использовалось дмя увеличения и защиты общественного блага против внутренних вызовов - понятие "национальный интерес" использовалось Аля продвижения целей внешней поАитики» $[6$, с. 121$]$.

Вместе с тем общественные и национальные интересы - не взаимоисключающие категории. Наџиональный интерес - категория абстрактная и весьма субъективная, так как ее содержание опредемяется картиной мира и ценностной системой, существуюшей в данном обшестве и государстве. М.В. Иıьин отмечает, что «наџиональный интерес есть интерес наџии как Авуединство суверенного территориального государства и гражданского общества. Государственный интерес и интересы гражданского общества содержательно связаны с понятием национального интереса и в значительной мере определяют его смысловую структуру» [7, с. 141]. При этом сущность национального интереса заключается в отношении, выражаюшем стремление государства и гражданского общества к Аостижению самосохранения государства $[8$, с. 16$]$. 
Несомненно, национальные интересы выражают наиболее существенные потребности российского общества и государства, удовлетворение которых способно обеспечить их устойчивое развитие, поэтому наџиональные интересы явмяются важнейшими задачами внутренней и внешней политики. В совокупности они образуют единую систему взаимообусловленных национальных интересов. Именно поэтому одной из важнейших пробкем современной науки конституџионного права является необходимость опредемения конкретных национальных интересов России и их иерархии [9].

Система национальных интересов России отражена в нормах действующего законодательства, в Посланиях Президента РФ Федеральному Собранию: национальные интересы в сфере национальной безопасности, пограничной сфере, внешнеполитическом курсе, сфере культуры, информаџионной сфере, области цифровой экономики, нащиональной экономики и т.А. Они отражают потребности государства, общества и кичности во всех областях экономической, общественной и политической жизни.

Пубцичный интерес, по мнению Ю.А. Тихомирова, в качестве конџентрированного выражения общесоџиальных потребностей и стремлений выступает системообразующим явлением и с юридической точки зрения характеризуется опредекенными нормативными признаками, закреплением его приоритета, установлением порядка и гарантий обеспечения, закреплением способов охраны и мер ответственности. Общее родовое понятие публичного интереса сочетается с видовыми нормативными понятиями, такими, как интересы общества и государства, наџиональной безопасности, общие интересы, интересы наций, народов, населения, общеэкономические интересы, интересы экологического благополучия, региональные и местные интересы, корпоративные интересы. В конџентрированном виде, считает Ю.А. Тихомиров, публичный интерес закрепляется в Конститущии РФ и скужит правообразующим Амя всех отраслей права, являясь при этом объектом отражения и закрепления и в отраслях частного права [10, с. 4-5].

Значение конституционного закрепления категории «интерес» заключается в том, что в этом случае интересы становятся юридическим средством обеспе-

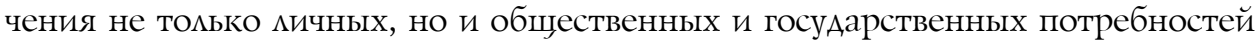
в различных сферах жизнедеятельности. На внутригосударственном уровне национальные интересы заключаются в обеспечении общественной, информационной, экономической, экологической, продовольственной, ядерной и радиационной безопасности.

В формулировании национальных интересов и формировании внешнеполитической стратегии, которая реализует их, большое значение имеет система џенностных ориентаџий, принџипов и убеждений государственных деятелей - восприятие ими современной геополитической ситуаџии в мире и оџенка места страны в ряду остальных государств, составцяющих мировое сообщество. Определение нащиональных интересов отдельно взятого государства предполагает обязательный учет интересов других государств, а в чем-то и интересов всего мирового сообщества. В этом контексте заслуживают 
внимания положения Конџепџии внешней политики России [11], органически связанной с общепризнанными принџипами и нормами международного права, и международными договорами Российской Федерации.

Обеспечение национальных интересов и реализация стратегических национальных приоритетов Российской Федерации требуют выполнения основных задач во внешнеполитической деятельности государства:

обеспечения безопасности страны, ее суверенитета и территориальной цемостности, укрепления правового государства и демократических институтов;

создания благоприятных внешних условий дмя устойчивого роста и повышения конкурентоспособности экономики России, ее технологического обновления, повышения уровня и качества жизни населения;

упрочения позиций Российской Федерации как одного из вАиятельных центров современного мира;

всесторонней эффективной защиты прав и законных интересов российских граждан и проживающих за рубежом соотечественников.

В таком контексте должны функционировать все органы государственной власти, согласуя все действия и решения с наџиональными интересами. Национальные интересы явцяются связующим элементом межАу жизненно важными потребностями и ценностями общества и государства и стратегическими цемями государственной политики. Именно национальные интересы задают направленность функџионирования государства и џелостной обшественной системы, а также прогрессивное развитие. В сфере обеспечения прав и свобод человека Россия в соответствии с универсальными демократическими ценностями стремится обеспечивать уважение прав и свобод человека во всем мире путем конструктивного, равноправного международного диалога с учетом национальных, культурных и исторических особенностей и џенностей каждого государства, осуществлять мониторинг ситуаџии с собмюдением прав человека в мире. Решение этой задачи возможно во взаимодействии с институтами гражданского общества, неправительственными организациями.

Безусловно, одна из главных задач государственной вмасти - обеспечение баланса интересов цичности, общества и государства, который явмяется важнейшей основой стабильности конституционно-правового развития Российского государства. Обеспечивая согласование интересов цичности, общества и государства посредством поиска консенсуса, государство способствует решению политических, экономических, соџиальных и иных проблем, где интересы становятся важным фактором конституџионной стабимьности в государстве.

В целом концепция национальных интересов, определяя приоритеты развития обшества, условия его самосохранения, место в геополитическом пространстве, способы взаимодействия с другими государствами, ориентирована на развитие политических, экономических, технологических, экологических, идеологических и правовых факторов, которые важны сегодня не только с точки зрения выживания, но и дяя успешного функционирования и развития институтов гражАанского общества, государства. 


\section{Библиографический список}

1. Бондарь Н.С. Ценность Конституции России как юридического акта и социокультурного явления (к 20-летнему юбилею) // Журнал конституционного правосудия. 2013. № 6.

2. Бондарь Н.С. Буква и дух российской Конституции: 20 -летний опыт гармонизации в свете конституционного правосудия // Журнал российского права. 2013. № 11.

3. Эбзеев Б.С. Конституция, государство и личность в России: философия российского конституционализма // Конституционное и муниципальное право. 2013. № 11.

4. О Стратегии национальной безопасности Российской Федерации: Указ Президента РФ от 31 дек. 2015 г. № 683 // С3 РФ. 2016. № 1 (ч. II). Ст. 212.

5. Баранов В.М. Деструктивное воздействие права и национальные интересы // Журнал российского права. 2005. № 12. С. 84-87.

6. Саидов А.Х., Кашинская Л.Ф. Национальная безопасность и национальные интересы: взаимосвязь и взаимодействие (опыт политико-правового анализа) // Журнал российского права. 2005. № 12.

7. Ильин М.В. Слова и смыслы: Опыт описания ключевых политических понятий. М., 1997.

8. Кардашова И.Б. О сущности национального интереса // Административное право и процесс. 2015. № 5.

9. Хижняк В.C. Классификация национальных интересов современной России // Конституционное и муниципальное право. 2008. № 5.

10. Тихомиров Ю.А. Публично-правовое регулирование: динамика сфер и методов // Журнал российского права. 2001. № 5 .

11. Об утверждении Концепции внешней политики Российской Федерации: Указ Президента РФ от 30 нояб. 2016 г. № 640 // СЗ РФ. 2016. № 49. Ст. 6886. 